\title{
脳室穿破を伴う視床出血に対する神経内視鏡的血腫除去術
}

\author{
林 央周, 遠藤 俊郎, 浜田 秀雄 \\ 梅村 公子, 高久 晃, 堀江 幸男*
}

\section{Endoscopic Evacuation of Thalamic Hemorrhage Associated with Intraventricular Hemorrhage}

Nakamasa HaYashi, M.D., Shunro Endo, M.D., Hideo Hamada, M.D., Kimiko Umemura, M.D., Akira TaKaku, M.D., and Yukio Horie, M.D.*

Department of Neurosurgery, Toyama Medical and Pharmaceutical University, and *Saiseikai Toyama Hospital, Toyama, Japan

\begin{abstract}
Summary: We describe a method of endoscopic evacuation of combined thalamic and intraventricular hemorrhage. We used a steerable endoscope that was inserted into the anterior horn of the lateral ventricle contralateral to the thalamic hemorrhage in 4 cases. Because the volume of the hematoma in the lateral ventricle contralateral to the cerebral hemorrhage was smaller than that of the ipsilateral lateral ventricle, the hematoma in the contralateral lateral ventricle could be easily evacuated and sufficient orientation was obtained in the interior of the lateral ventricle. Hematoma in the third ventricle and the aqueduct of Sylvius could also be evacuated by the endoscope passed through the foramen of Monro. We then performed septostomy, and inserted the endoscope into the lateral ventricle ipsilateral to the cerebral hemorrhage. The hematoma in the ipsilateral lateral ventricle and the cerebral hemorrhage could be adequately evacuated. We conclude that approach to thalamic hemorrhage from the lateral ventricle contralateral to the cerebral hemorrhage through an opening placed in the septum pellucidum is useful for the treatment of combined thalamic and intraventricular hemorrhage.
\end{abstract}

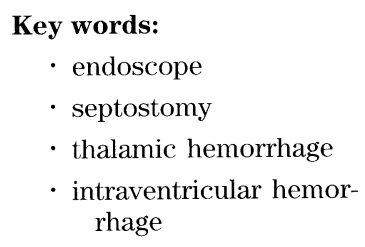
rhage

Surg Cereb Stroke (Jpn) 27: 110-114, 1999

\section{はじめに}

神経内視鏡は脳神経外科領域における応用がすすみ，水 頭症治療や脳室内および囊胞性病変に対する治療に大きな 効果を発揮してきている ${ }^{4)}$ (10). 特に, 細径の軟性鏡は先 端を大きく彎曲することができるため, 脳室内での操作性 に優れており, 脳室内を十分に観察することができる利点 を有している4).われわれは，この軟性脳室鏡の自由な操
作性を利用して，脳室穿破を伴う視床および尾状核部出血 に対して，脳坴内出血を除去し，さらに血腫の脳室穿破部 位から血腫腔内に内視鏡を挿入して脳内血腫除去を行っ た。その手術手技および脳室鏡所見を中心に報告する。

\section{対象および方法}

対象は脳室穿破を伴う視床出血 3 例および尾状核部出血. 1例である(Table 1)。本論文では脳室内の血腫により， 富山医科薬科大学 脳神経外科, *済生会富山病院 脳神経外科(受稿日 1998.9.14)〔連絡先： T 930-0152 富山市杉谷 2630 富山医科 薬科大学 脳神経外科 林 央周〕〔Mailing address: Nakamasa HAYASHI, M.D., Department of Neurosurgery, Toyama Medical and Pharmaceutical University, 2630 Sugitani, Toyama 930-0152, Japan] 


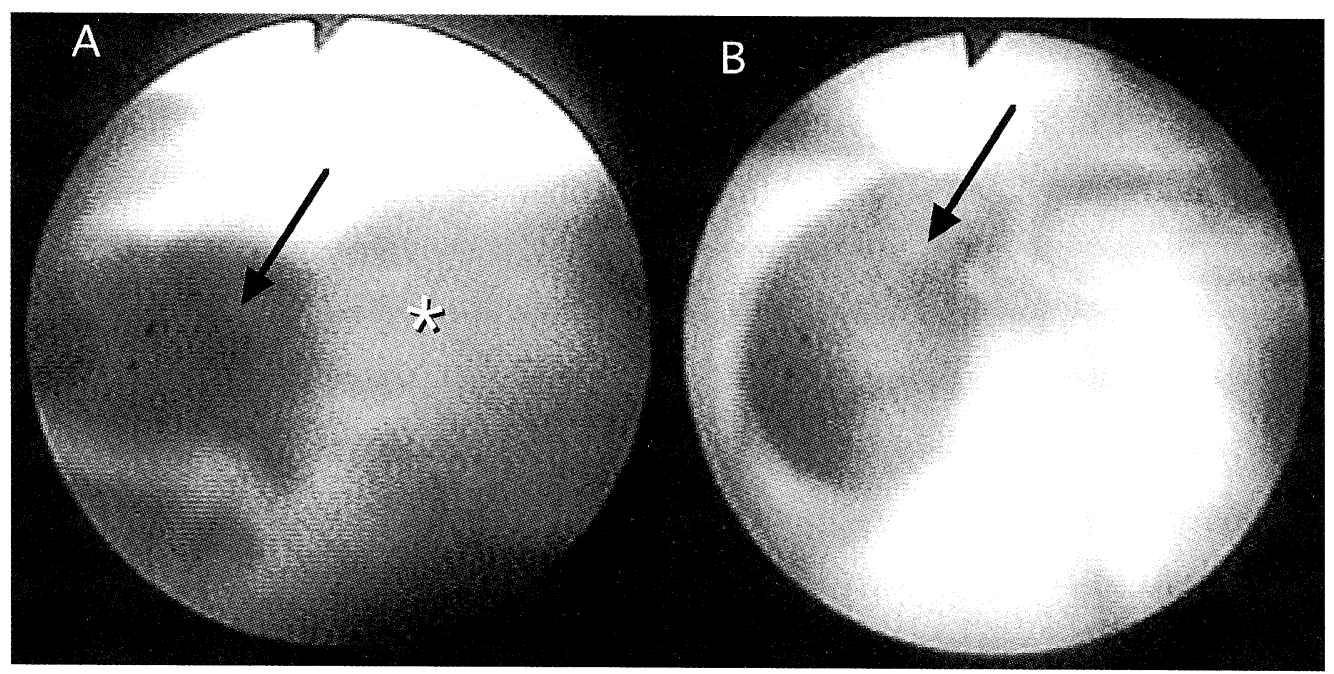

Fig. 1 Endoscopic views. A: The hematoma in the lateral ventricle contralateral to the thalamic hemorrhage. Note the foramen of Monro is blocked by the hematoma (*). B: The foramen of Monro was clearly seen after the evacuation of the hematoma. Arrow indicates the foramen of Monro.

Table 1 Summary of cases treated using endoscope

\begin{tabular}{ccllll}
\hline No. & Age $/$ Sex & Site of hematoma & Timing of the surgery & Rate of evacuation & Results \\
\hline 1 & $84 / M$ & left thalamus & 5 days & $55 \%$ & improve \\
2 & $83 / \mathrm{F}$ & right thalamus & 8 hours, 7 days & $62 \%$ & no change \\
3 & $73 / M$ & right thalamus & 7 days & $79 \%$ & no change, NPH \\
4 & $56 / M$ & right caudate nucleus & 6 hours & $52 \%$ & improve \\
\hline
\end{tabular}

急性期に閉塞性水頭症をきたした症例もしくは経過中に䯣 液循環障害をきたしていると考えられた症例を対象とし た.

使用した内視鏡は Codman 社製スティーラブルエンド スコープである．脳室へのアプローチは血腫と反対側の側 脳空前角より行った。透明中隔開空術を行うため，内視鏡 を透明中隔の面に対してできるだけ垂直に向けることがで きるように，穿頭部位はやや外側 (3横指)に置いた。14Fr のピールアウェイシースを側脳室前角に扱入後, 内視鏡を 用いて血腫と反対側の側脳室前角部の血腫を吸引除去し た、モンロー孔を確認して, 内視鏡を第三脳室へ進め, 中 脳水道の血腫を除去した。脳室穿破部位が第三脳室側壁に ある場合には，そこから脳室鏡を血腫腔内に進めて血腫除 去を行った．この場合，穿破部位周辺の第三脳室壁に侵襲 が加わらないよう，十分に脳室内を洗浄して内視鏡視野を 確保したうえで，慎重に内視鏡を進めるように留意する必 要があった。次に, 内視鏡用電気凝固装置である $\mathrm{ME} 2$ を 用いて透明中隔開空術を行い，血腫側の側脳室に入り，前 角部の血腫を除去した。さらに側脳室体部の脳室穿破部位 から血腫腔内に内視鏡を扦入して脳内血腫除去を行った。
脳室内出血抢よび脳内血腫は内視鏡のワーキングチャン ネルより，注射器を用いて用手的に㓌压を加えることによ り除去した.

内視鏡操作中は十分な内視鏡視野を得るために, リンゲ ル液を用いて血腫の吸引・洗浄を繰り返し行った. 2 例で は内視鏡操作中の過剩洗浄による脳圧充進を避ける目的 で，血腫側側脳室前角に脳室ドレナージを挿入した。

\section{結 果}

血腫と反対側の側脳室前角の血腫は血腫側に比べて少な く, 容易に吸引除去することができ, また, 洗浄を繰り返 すことによって十分な内視鏡視野を得ることができたた め，モンロー孔を確実に確認することができた(Fig. 1). この操作により，内視鏡を第三脳室へ挿入することができ， 第三脳室掞よび中脳水道の血腫を除去することができた (Fig. 2). 第四脳室の血腫を除去することはできなかった. ついで，モンロー孔の上方で前中隔静脈の後方に透明中 隔開放術を行った。中隔はME2を用いて円形に開空を行 ったが，全例で十分な大きさの透明中隔開放を行い得た

(Fig. 3)。この開空部位から内視鏡を血腫側の側脳室に挿 

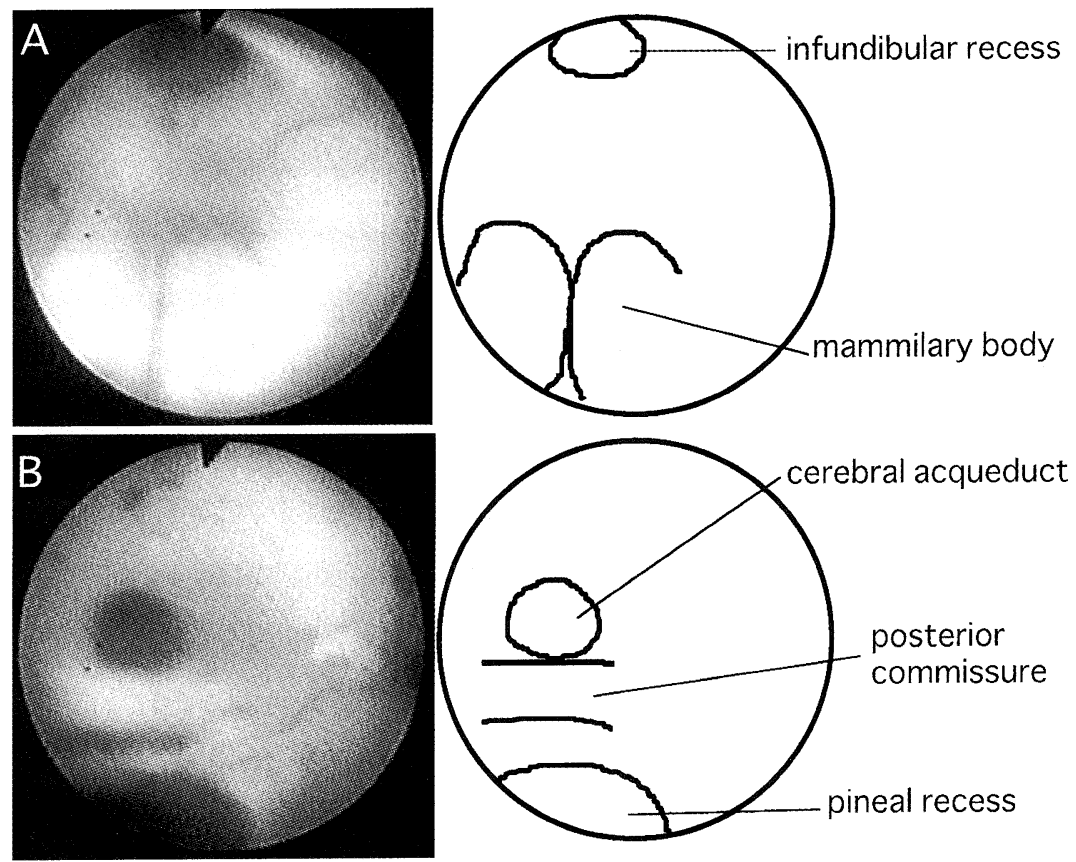

Fig. 2 Endoscopic views and schematic drawings after evacuation of the hematoma in the third ventricle. A: The floor of the third ventricle. B: The cerebral aqueduct.

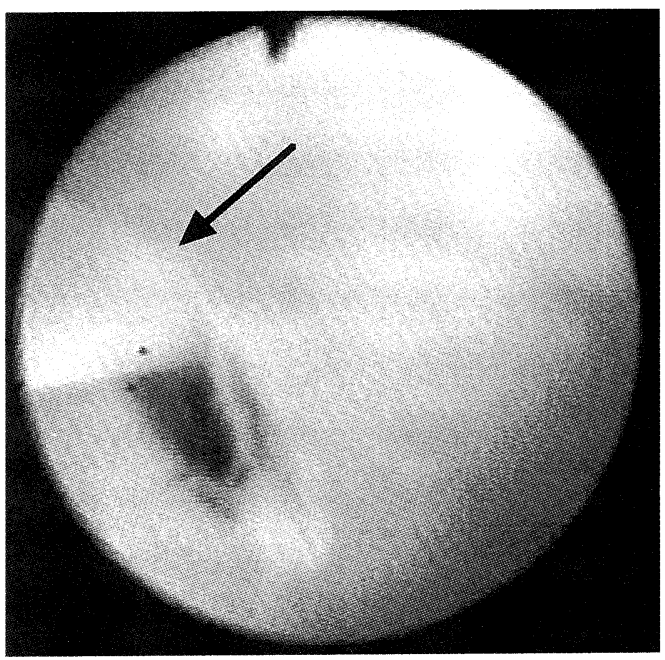

Fig. 3 Septostomy. Arrow indicates ME2

入し，血腫側側脳室内の血腫の吸引および洗浄を行った。 血腫反対側から内視鏡を挿入することにより，内視鏡に無 理な彎曲操作を加えることなく，側脳室体部の脳空壁穿破 部位を正対して観察することができた（Fig. 4)。さらに， 血腫腔内へ内視鏡を扱入して，血腫内を観察しながら吸引 操作を行った。Fig. 5 に症例 1 の術前後のCTを示した. 血腫の吸引は用手的に陰圧を加えることによって行った が，吸引操作中に新たな出血などは認めなかった。また，

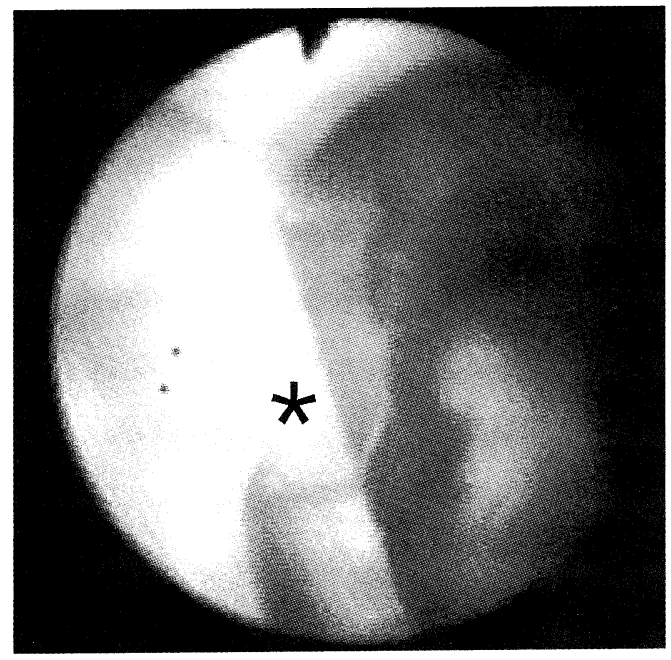

Fig. 4 Endoscopic view in the lateral ventricle ipsilateral to the thalamic hemorrhage. The drainage tube inserted in the lateral ventricle ipsilateral to the thalamic hemorrhage is seen (*)

出血点と思われる小血管の断端は認められなかった.

発症後6時間目に血腫除去を行った症例 (Case 4)では, 脳室内の血腫および尾状核部の血腫は比較的容易に吸引す ることができた。発症後 8 時間目に血腫除去を行った症例 (Case 3)では，血腫が固くほとんど吸引することができな かったため, 発症 7 日目に再手術を行った. 発症 5 日目以 


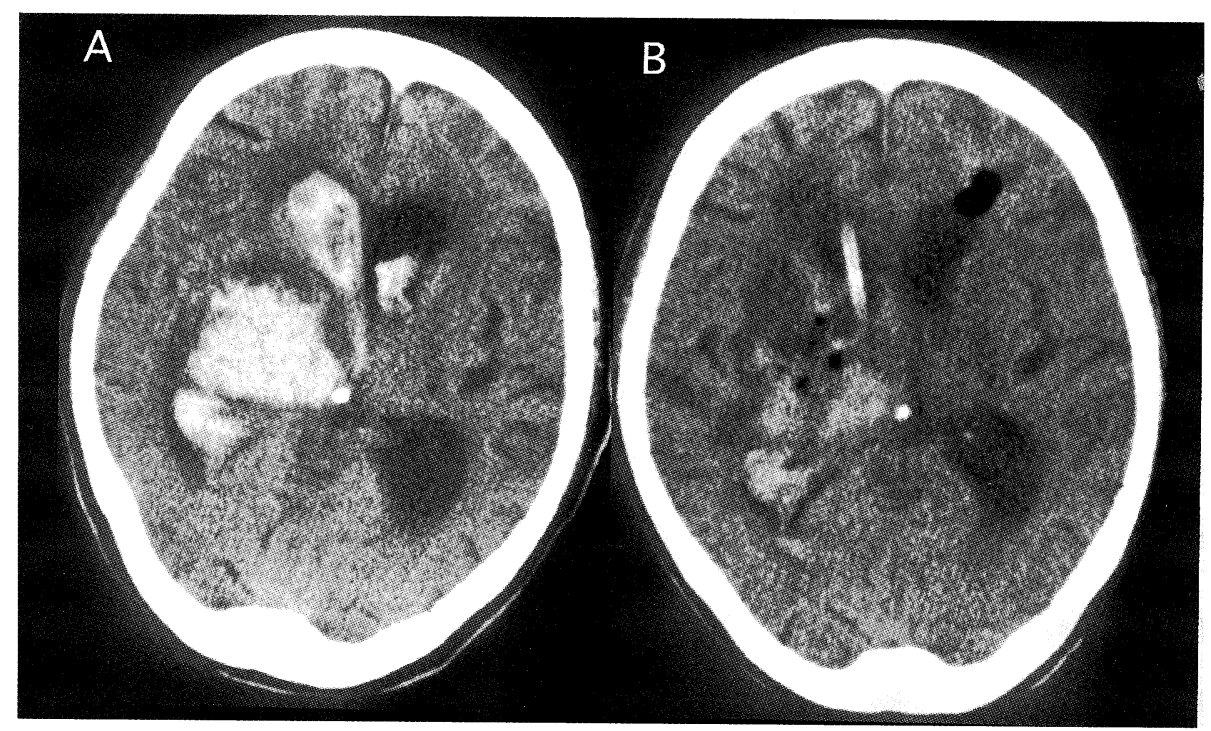

Fig. 5 Preoperative $|\mathbf{A}|$ and postoperative $(\mathbf{B} \mid \mathbf{C T}$ in Case 2. The endoscope is inserted from the lateral ventricle contralateral to the thalamic hemorrhage.

降の血腫は柔らかく, 吸引除去を容易に行うことができた。 脳室内の血腫はほほ吸引除去されたが, 脳内の血腫除去の 程度は 50-80\%であった(Table 1)。

術後，全例で脳圧測定の目的で，一側の側脳室前角に持 続脳室ドレナージを留置した，脳圧はいずれも正常範囲内 であり，術後 3-5 日で抜去することができた。術後の経過 は, 2 例で不変, 2 例で術直後より改善を認めた。症例 3 では術後 1 カ月の経過で徐々に脳室が搪大したため, 正常 圧水頭症と診断して脳室腹腔シャントを行った。

\section{考察}

被壳出血や視床出血などの媣部脳内出血に対する治療と して, 定位的血腫除去術が普及している。この手技は侵襲 が少なく, 確実に血腫内に吸引管を進められるなどの利点 があるが，手術操作は盲目的であり，術中に血腫除去の程 度を確認することは容易ではなく，また，吸引術中に出血 血管からの新たな出血をきたした場合に対処することがで きないなど手術の確実性に問題点が指摘されている，血腫 吸引術後の再出血率は金谷らによると $6 \%$, 岩渕らによる と $7.8 \%$ と報告されている778).この定位的血腫除去術の久 点を克服する目的で，硬性内視鏡を用いた血腫吸引術が報 告されている(1) 2) 9).この方法では, 血腫腔内の観察によ る的確な吸引操作とともに, 残存血腫の確認や小血管から の出血に対する止血などが可能になる. Auerらはこの方 法を用いて脳内血腫除去を行い，内科的加療の場合との予 後の差について検討している。，その結果，皮質下出血では 良好な結果が得られるものの, 被殼㧍よび視床出血では内 科的加療と比べて有意な差が認められなかったと報告して
いる ${ }^{3)}$. 一方, 黑田らは内視鏡的血腫吸引術により, 平均 血腫吸引率 $85 \%$ と良好な結果を得たと報告しておりり ${ }^{9)}$, 今 後, 内視鏡の応用による血腫吸引率の向上によって, 外科 的治療成績の向上が得られることが期待される.

われわれは, 軟性鏡を用いて, 血腫と反対側の側脳室前 角よりのアプローチにより脳室内抢よび脳内の血腫の除去 を行った。軟性鏡は硬性鏡に比べて, 得られる視野の鮮明 度は低下するが，今回の検討では十分な視野を得ることが できた。血腫と反対側の側脳室内では血腫量が少ないた め, この脳室内の血腫は容易に吸引・洗浄により除去する ことができ, 手術早期に重要な解剖学的指標であるモンロ 一孔を視野に納めることができた。これにより，内視鏡を 確実に第三脳室へ挿人でき，また，安全に透明中隔開放術 を行うことができた。また，反対側の側脳室前角から透明 中隔開放部を経由してアプローチすることにより，内視鏡 に無理な彎曲操作を加えることなく，血腫の脳室穿破部位 へ挿入することができ，血腫吸引の操作も行うことができ た（Fig. 5)。透明中隔開放術は比較的容易で安全な手術手 技であり，本法は有用な方法であると思われた，また，本 法では, 脳室内の血腫, 特にモンロー孔や中脳水道の血腫 を十分除去することにより，急性期の水頭症に対する治療 に効果があったと考えられた。しかしながら 1 例で続発し た正常圧水頭症により脳室腹腔短絡術を必要とした。脳室 内出血に合併する正常压水頭症の発生に対する，早期の䑈 室内血腫除去による予防効果についてはさらなる検討が必 要であると考えられた。

われわれは, 脳内の血腫の吸引は脳室穿破部位より行い, 深部の除去は十分行わないため, 吸引操作中に出血点と思 
われる小血管の断端は認められなかった. 内視鏡用電気凝 固装置である ME2 やレーザーなど, 内視鏡用の止血装置 が開発されているが，内視鏡術野での止血操作は容易なも のではない，脳室穿破部位より血腫を吸引する操作は, 術 中の出血や再出血による血腫の増大を予防するうえでは, むしろ有用であると考えられる。しかしながら, 血腫除去 率は 50-80\% と必ずしも満足すべきものではなく, 血腫除 去術を行う時期の検討や血腫吸引のための装置に工夫が必 要である。蛯名らは細径の超音波破砕装置を使用して固い 凝血塊も吸引できることを報告しており ${ }^{5)}$ ，このような装 置を使用することにより，さらに良好な吸引率を得ること が期待される.

\section{ま と め}

軟性内視鏡を用いた脳室内の手術操作では，良好な視野 を得るために十分な洗浄を行い, モンロー孔などの重要な 解剖学的指標を確実にとらえることが重要である。この点 で，血腫反対側の側脳室からアプローチする方法は有用で ある。また，透明中隔開放術を行うことにより，軟性鏡の 自由な操作性を活かして吸引操作を行うことができた．脳 室内出血を伴う深部脳内出血の治療法のひとつとして有用 な方法であると考えられた。

\section{文献}

1) Auer LM, Ascher PW, Heppner F, et al: Does acute endoscopic evacuation improve the outcome of patients with spontaneous intracerebral hemorrhage? Eur Neurol 24: 254-261, 1985

2) Auer LM: Endoscopic evacuation of intracerebral hemorrhage: High-tec-surgical treatment-A new approach to the problem? Acta Neurochir 74: 124-128, 1985

3) Auer LM, Deinsberger W, Niederkorn K, et al: Endoscopic surgery versus medical treatment for spontaneous intracerebral hematoma: a randomized study. J Neurosurg $\mathbf{7 0 \text { : }}$ 530-535, 1989

4) Cohen AR: Endoscopic ventricular surgery. Pediatric Neurosurg 19: 127-134, 1993

5）蛯名国彦, 金 奉均, 鈴木重晴, ほか：脳内血腫除去にお ける定位的脳手術用内視鏡システムの開発と臨床応用. 脳 卒中の外科 23: 109-115, 1995

6) Gaab MR, Schroeder HWS: Neuroendoscopic approach to intraventricular lesions. J Neurosurg 88: 496-505, 1998

7）岩㴊隆：高血压性脳出血（1）被凯出血. 脳卒中 12 : 525-540, 1990

8）金谷春之：高血圧性脳出血の治療の現況一全国調査の成績 より。脳卒中 12: 509-524, 1990

9）黑田清司，小川彰：脳内血腫除去術. Neuroendoscopic surgery：神経内視鏡の基礎知識と手術手技，三輪書店，東 京, 1996, pp193-198

10）岡一成, 朝長正道: 水頭症に対する神経内視鏡手術. 脳 神経外科 25: 883-892, 1997 